Appl. Ent. Zool. 1 (2) : $61-68$ (1966)

\title{
The Acid-Soluble Nucleotides of Royal Jelly
}

\author{
Takashi Mitsui and Takao Sagawa \\ Research Laboratories of Chugai Pharmaceutical Co. Ltd., Tokyo, Japan
}

(Received March 3, 1966)

\begin{abstract}
In order to study the relationship between the queen differentiation and nucleotides, acid-soluble nucleotides of royal jelly, which was taken from queen cells at different stages, and worker jelly of honey bee, Apis mellifera $\mathrm{L}$. were analysed by Dowex-1 (formate form) ion exchange column chromatography. The fractions, separated by this procedure, were identified with paper chromatography, paper electrophoresis and chemical analysis. The differences were not found in quality but in quantity of each sample. The rate of base composition of total nucleotides was approximately same in each sample, about 50 per cent adenosine, 30 per cent uridine, 5 to 7 per cent guanosine and small amount of cytidine nucleotides. The total contents of nucleotides were found to be highest in $48 \mathrm{RJ}$. UDP and UDP-sugar type nucleotides were found in large amount in royal jelly which was taken from early stage of queen cells.
\end{abstract}

\section{INTRODUCTION}

It is well known that the queen differentiation depends upon the food given to the larvae of honey bee, Apis mellifera L. A number of investigators have tried to discover the biologically active substances in royal jelly. Recently, the chemical differences between royal jelly and worker jelly were reviewed by REMBOLD(1961). According to his conclusion, royal jelly differed from worker jelly quantitatively in its content of folic acid, pantothenic acid and biopterin.

In order to study the relationship between the queen differentiation and nucleotides, which are of biological importance, we tried chemical analysis of these compounds in royal jelly and worker jelly. REMBOLD (1961) separated and identified some of nucleotides in royal jelly. Recently, on the way of our studying, MARKo and PECHAN (1964) reported the nucleotides in royal jelly. This paper deals with the identification and comparison of acid-soluble nucleotides of royal jelly taken from queen cells at different stages. Further comparative studies of these compounds in commercial jelly and worker jelly were made.

\section{MATERIALS AND METHODS}

Samples Royal jelly was taken from queen cells 24,48 and $72 \mathrm{hr}$ after grafting, which is shown as $24 \mathrm{RJ}, 48 \mathrm{RJ}$ and $72 \mathrm{RJ}$, respectively (Mitsui et al., 1964). A commercial jelly of undetermined origin and age was also used (Comm. RJ). Worker jelly was taken from worker combs after removing the worker larvae, about 3 to 4 days old.

Preparation of acid-soluble fraction All samples were lyophilized and $15 \mathrm{~g}$ of 
these materials was extracted by means of $150 \mathrm{ml}$ of ice-cold $0.5 \mathrm{~N}$ perchloric acid (PCA). The precipitated protein was centrifuged and extracted again with $100 \mathrm{ml}$ of ice-cold $0.2 \mathrm{~N}$ PCA. After neutralization with $5 \mathrm{~N} \mathrm{KOH}, \mathrm{KClO}_{4}$ was precipitated as completely as possible by chilling the solution. Then the supernatant fluid was filtered and concentrated to less than $50 \mathrm{ml}$ by lyophylization. All procedures were carried out at $6^{\circ} \mathrm{C}$.

Ion exchange chromatography The procedures for the preparation of column and gradient elution were based essentially on those of HURLBART et al. (1954), using a column of Dowex-1X8 (200 to 400 mesh) in the formate form, dimension $3 \mathrm{~cm} \times 10 \mathrm{~cm}$ (Type I system). Rechromatography was carried out by gradient elution with ammoniurn formate, dimension $1 \mathrm{~cm} \times 10 \mathrm{~cm}$ (Type II system). Elutions were carried out at $5{ }^{\circ} \mathrm{C}$. Usually the fractions were lyophilyzed to remove the formic acid in closed vacuum desiccators with a $3: 1$ mixture of $\mathrm{NaOH}-\mathrm{CaCl}_{2}$ (Busch et al., 1952). In fractions containing ammonium formate, the $\mathrm{NH}_{4}{ }^{+}$was exchanged for $\mathrm{H}^{+}$, using the Dowex-50 in $\mathrm{H}^{+}$form and the solution was lyophilyzed (Johke, 1963). The optical density of the fractions, $10 \mathrm{ml}$ each, obtained by the ion exchange chromatography (Type I system, rate of flow $20 \mathrm{ml} / \mathrm{hr}$ ) was read at $260 \mathrm{~m} \mu$ with distilled water as a blank. For further chromatography, individual peaks were pooled and the eluents were removed. After rechromatography (Type II system), the optical density of each fraction $(5 \mathrm{ml}$ each) was measured at 260 $\mathrm{m} \mu$ and $275 \mathrm{~m} \mu$. The individual peaks were collected and concentrated for further analysis.

Identification of the nucleotides in the various peaks The base moiety was identified by ratios of the reading at $260 \mathrm{~m} \mu$ and $275 \mathrm{~m} \mu\left(\mathrm{E}_{275} / \mathrm{E}_{260}\right)$ and by shifts in spectrum in both $0.1 \mathrm{~N} \mathrm{HCl}$ and $0.1 \mathrm{~N} \mathrm{NaOH}$. In several cases, the base moiety was also identified by paper chromatography after hydrolysis with $12 \mathrm{~N} \mathrm{PCA}$ at $100^{\circ} \mathrm{C}$ for $60 \mathrm{~min}$ in the following solvent systems.

P-1: $85 \%$ saturated aqueous solution of ammonium bicarbonate $(16 \mathrm{~g} / 100 \mathrm{ml}$ ) (HEMS, 1959)

P-2: isobutyric acid + conc. ammonia + water (661:10:329) pH 3.7

P-3: $95 \%$ ethanol $+1 \mathrm{M}$ ammonium acetate $(7: 3)$ (BLock et al., 1958)

P-4: n-butanol + water (86:14) (CHARGAFF and DAvIDSON, 1955)

Phosphorus content was determined by the method of ALLEN (1940). The content of ribose was determined by orcinol reaction. The carbohydrate moiety of sugar-containing nucleotides was identified with paper chromatography and thin-layer chromatography after hydrolysis of nucleotides in $0.01 \mathrm{~N} \mathrm{HCl}$ at $100^{\circ} \mathrm{C}$ for $30 \mathrm{~min}$ in the following systems.

Paper chromatography

P-5 water saturated phenol $+1 \%$ ammonia

P-6 water saturated collidine (BLock et al., 1958)

Thin-layer chromatography

T-1: ethylacetate $+65 \%$ isopropanol (65:35) (STAHL and KALENBACH, 1961)

Sugar was detected with benzidine reagent, silver nitrate solution and ninhydrin. The concentrated fractions and its degradation products after hydrolysis with 0.01 $\mathrm{N} \mathrm{HCl}$, at $100{ }^{\circ} \mathrm{C}$ for $15 \mathrm{~min}$ were examined by means of paper chromatography in $\mathrm{P}-1$ to $\mathrm{P}-4$ solvent systems and paper electrophoresis, $0.05 \mathrm{M}$ ammonium acetate (pH 5), 5,000 volt for $40 \mathrm{~min}$, with some of authentic samples. For the estimation 


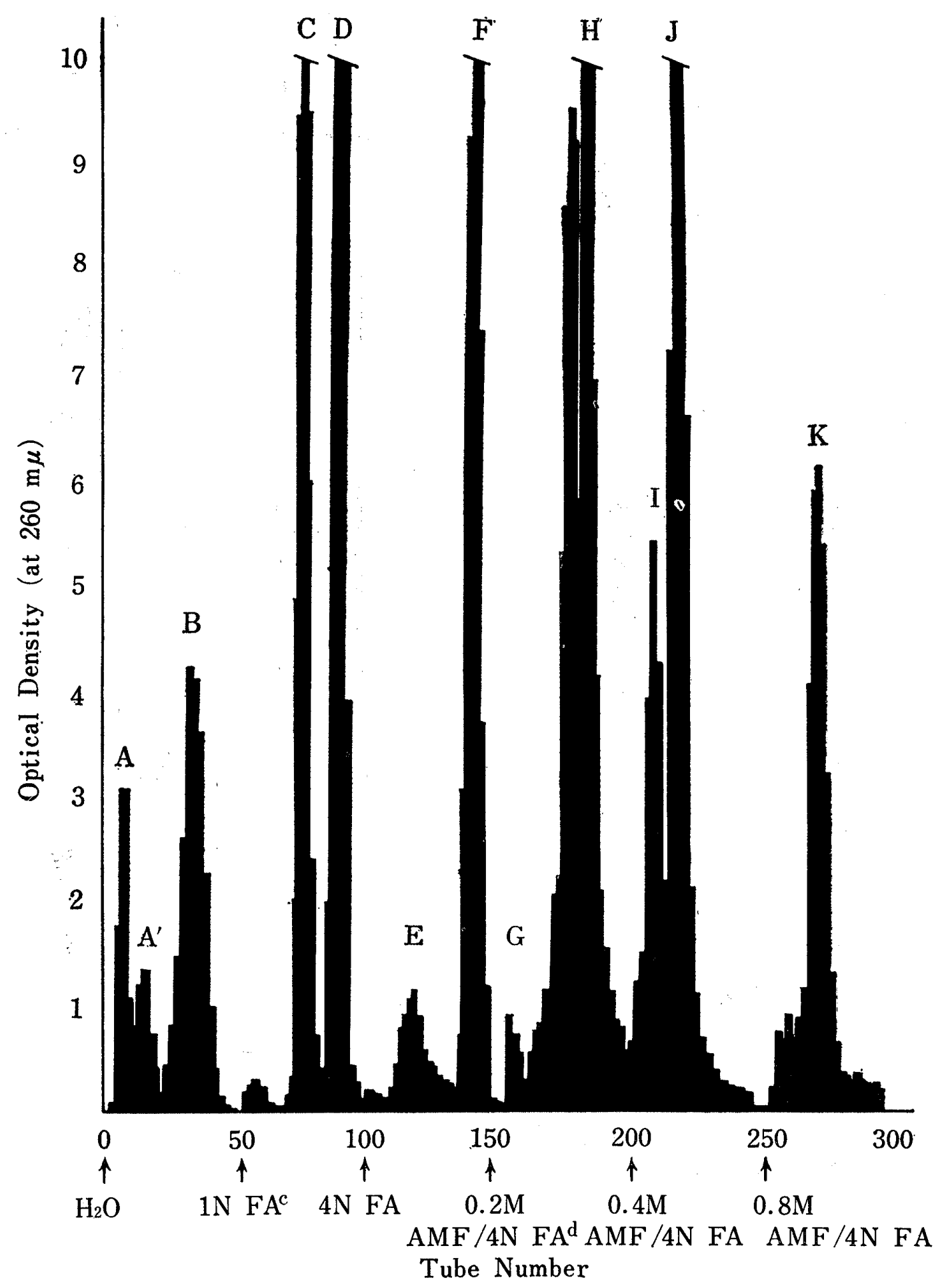

Fig. 1. A typical chromatogram for nucleotides of royal jelly. $c$ : formic acid; $d$ : $0.2 \mathrm{M}$ ammonium formate in $4 \mathrm{~N}$ formic acid. 
of nucleotides, the following extinction coefficients at $260 \mathrm{~m} \mu$ were used ( $\mathrm{pH} 2)$.

Adenosine nucleotides $\quad 14100$

Guanosine nucleotides $\quad 13300$

Uridine nucleotides $\quad 9900$

Cytidine nucleotides $\quad 13700$

\section{RESULTS}

The typical chromatogram (Type I system) for the nucleotides of royal jelly is shown in Fig. 1. Three major peaks, from fraction $\mathrm{A}$ to $\mathrm{B}$, and nine peaks, from fraction $\mathrm{C}$ to $\mathrm{K}$, were obtained in distilled water eluent and the following eluents respectively. Fraction A to B were mainly composed of bases and nucleosides, which were also recorded as optical density units at $260 \mathrm{~m} \mu$ in Table 1. The main nucleotides components of each fraction were identified as follows.

Fraction $C$ (cytidine nucleotide, NAD, adenosine nucleotide) By rechromatography (Type II), this fraction was separated into two main peaks, one of which had apparently two components " $\mathrm{C}-1$ " and "C-2", shown in Fig. 2. "C-1" had similar ultraviolet absorbing properties as cytidine nucleotides. The $\mathrm{Rf}$ values of this fraction on paper chromatography in several solvent systems differed from those of several mono-cytidine nucleotides or di-nucleotide-sugar. " $\mathrm{C}-2$ " proved to

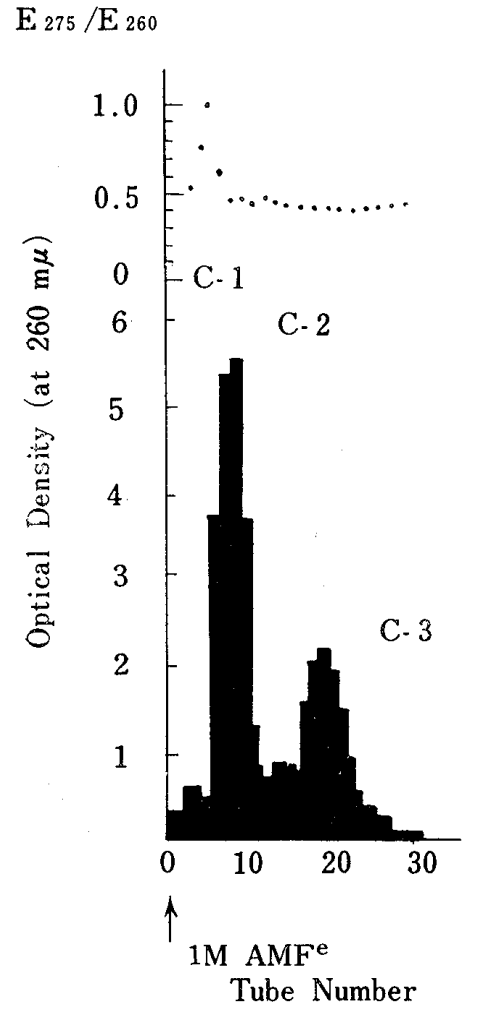

Fig. 2. Rechromatography of fraction C. e: AMF : ammonium formate. Dotted line shows the ratios of the reading at $260 \mathrm{~m} \mu$ and $275 \mathrm{~m} \mu$.

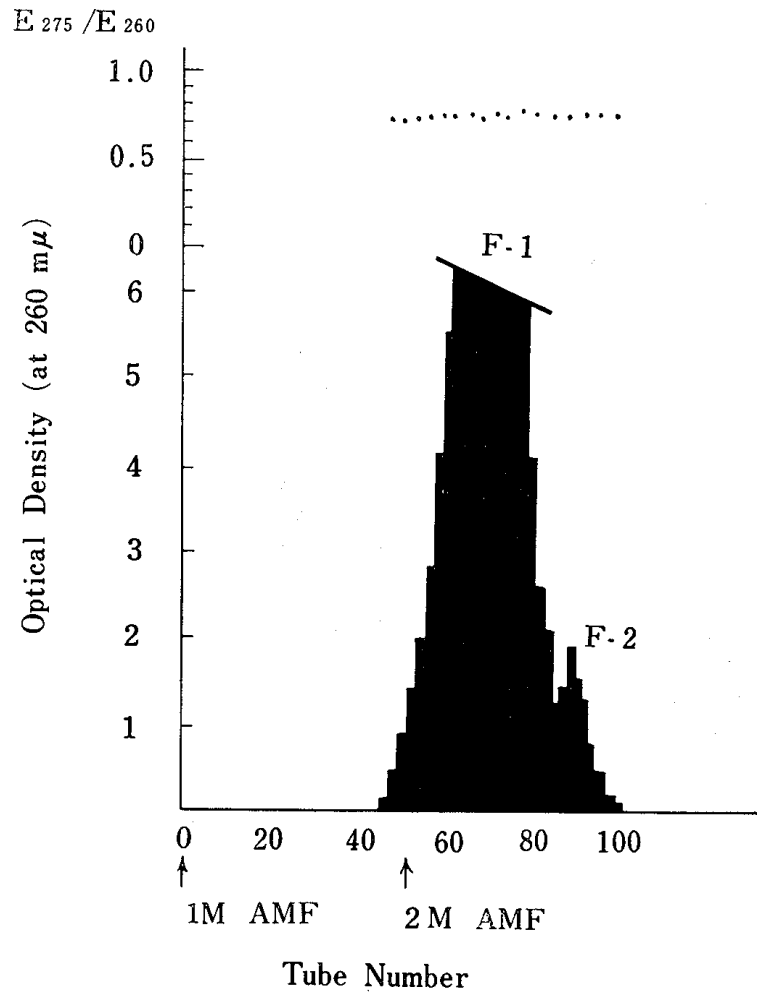

Fig. 3. Rechromatography of fraction F. Dotted line: as in Fig. 2. 
be NAD on paper chromatography with authentic sample. The ultraviolet absorbing properties of fraction "C-3" showed the presence of adenine derivatives. It remained, however, unidentified on paper chromatography with various authentic samples.

Fraction $D(5, A M P)$ Only one spot was detected on paper chromatography. The ultraviolet absorbing properties showed the presence of adenine derivatives. The ratio of adenine to ribose to total phosphorus was $1: 1: 1$. This fraction had the same Rf values as the authentic sample by paper chromatography in several solvent systems.

Fraction E (adenosine nucleotide) On paper chromatography, only one spot was obtained, which could not be identified. The characteristic ultraviolet absorption curve was that of adenosine nucleotides, the molar ratio of adenine, ribose, total phosphorus was approximately $1: 2: 1.3$. The Rf values of this fraction on paper chromatography differed from that of several mono- and di-nucleotides.

Fraction F (5' GMP, guanosine nucleotide) By rechromatography (Type II), two peaks, "F-1" and "F-2", were obtained, both of which had similar ultraviolet absorbancy as guanosine nucleotides (Fig. 3). The ratio of guanine to ribose to total phosphorus of "F-1" was $1: 0.9: 1.1$. "F-1" had the same Rf values as authentic sample, 5' GMP, on paper chromatography. "F-2" was not in enough quantity to carry on further analysis.

Fraction $G$ This fraction did not have any absorption peak in the region of $220 \mathrm{~m} \mu$ to $320 \mathrm{~m} \mu$, but contained ribose and phosphorus.

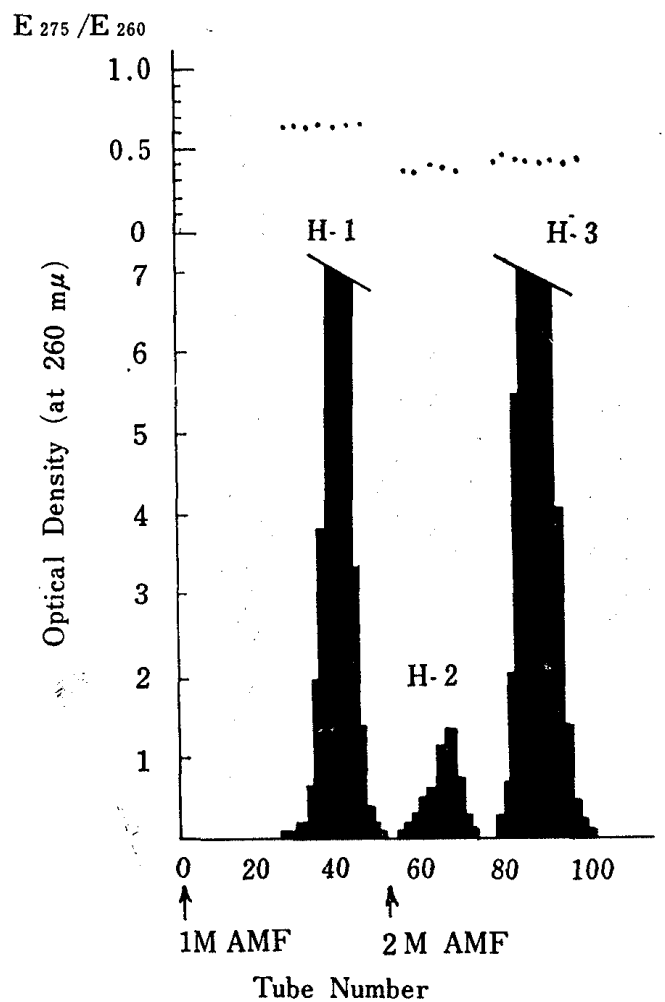

Fig. 4. Rechromatography of fraction $H$. Dotted line: as in Fig. 2.

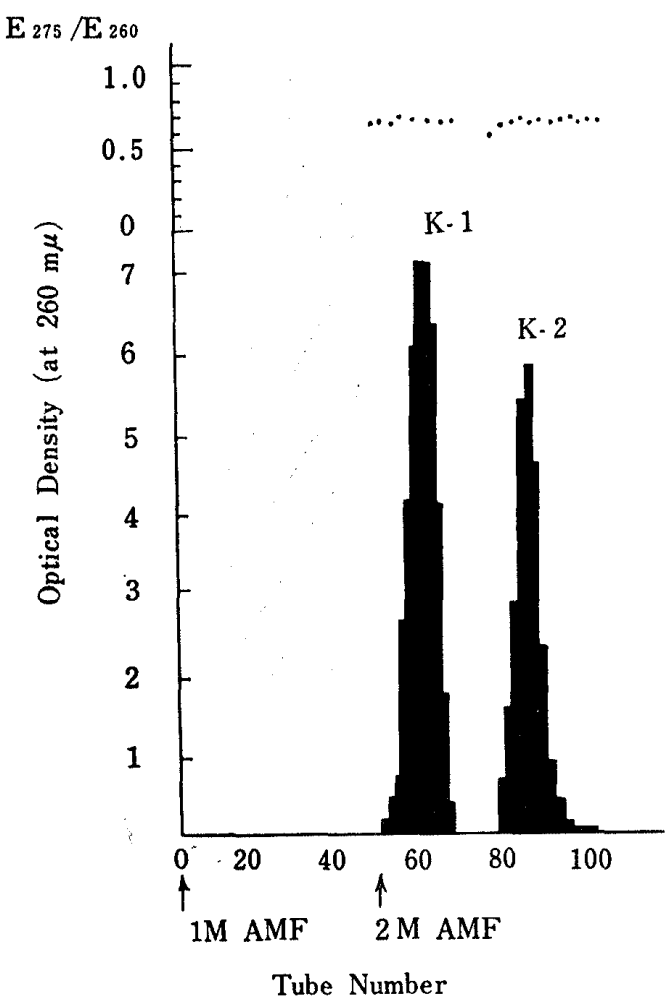

Fig. 5. Rechromatography of fraction $K$. Dotted line: as in Fig. 2. 
Fraction $H$ (5' UMP inosine nucleotide, ADP) This fraction was separated to 3 peaks on rechromatography (Type II) as shown in Fig. 4. The main component of "H-1" was 5' UMP, in view of ultraviolet absorption curve, determination of ribose and total phosphorus and paper chromatography with authentic sample. "H2" proved to be inosine derivatives by the ultraviolet absorption ratios. The ultraviolet spectroscopic examination of " $\mathrm{H}-3$ " proved to be the occurrence of adenine derivatives. The molar ratio of adenine, ribose, total phosphorus was approximately $1: 1.1: 1.8$. ADP was main component of this fraction on paper chromatography and electrophoresis with authentic sample.

Fraction I $(U D P-G)$ Ultraviolet absorbing properties and paper chromatography after hydrolyzing with $12 \mathrm{~N} \mathrm{PCA}$ for $60 \mathrm{~min}$ at $100^{\circ} \mathrm{C}$ showed this fraction to be uracil derivative. Chemical analysis gave uracil, ribose and total phosphorus ratio of approximately $1: 0.1: 2$. Two spots were detected on paper chromatography and electrophoresis, the minor spot of which was identified as UDP with authentic sample, the major spot of which was also identified as UDP after hydrolyzing with $0.01 \mathrm{~N} \mathrm{HCl}$ for $30 \mathrm{~min}$ at $100^{\circ} \mathrm{C}$. The sugar components of these nucleotides were studied by chromatography and thin-layer chromatography after hydrolyzing with $0.01 \mathrm{~N} \mathrm{HCl}$ for $30 \mathrm{~min}$ at $100^{\circ} \mathrm{C}$. The $\mathrm{Rf}$ values of this component were approximately same as glucose.

Fraction $J\left(U D P, U D P-G A, U D P-X_{1}\right)$ On paper chromatography and electrophoresis, three spots were obtained, the one (minor) spot of which was identified as UDP and the others (main) were found to be composed of UDP-sugar type by following similar procedures mentioned above. One of the sugar components of these nucleotides was ascertained to be glucuronic acid, but the other was unidentified by paper and thin-layer chromatographic studies.

Fraction $K\left(U D P-X_{2}, U-X_{3}\right)$ The peaks, "K-1" and " $\mathrm{K}-2$ " were separated from this fraction by rechromatography (Type II) as shown in Fig. 5. The fraction "K-1" was a nucleotide of UDP-sugar type, the sugar component of which was unidentified. The ultraviolet absorption of "K-2" showed the uridine nucleotides.

Chemical analysis gave uracil, total phosphorus ratio of $1: 1.9$. However, on

Table 1. The Contents of Acid-Soluble Nucleotides of Royal Jelly

\begin{tabular}{|c|c|c|c|c|c|c|c|c|c|c|c|c|c|c|}
\hline \multirow{2}{*}{ Sample } & \multicolumn{13}{|c|}{ Fraction } & \multirow{2}{*}{ Total } \\
\hline & & $A-B$ & $\mathrm{C}$ & $\mathrm{D}$ & $\mathrm{E}$ & $F$ & $\mathrm{G}$ & $\mathrm{H}-1$ & $\mathrm{H}-2$ & $\mathrm{H}-3$ & I & $\mathrm{J}$ & $\mathrm{K}$ & \\
\hline $24 \mathrm{RJ}$ & $\begin{array}{l}\mathrm{E}_{260} \mathrm{a} \\
\mu \mathrm{mol}\end{array}$ & 33.5 & 21.8 & $\begin{array}{r}329.0 \\
23.3\end{array}$ & $\begin{array}{l}6.2 \\
0.4\end{array}$ & $\begin{array}{r}49.4 \\
3.7\end{array}$ & 3.9 & $\begin{array}{r}24.7 \\
2.5\end{array}$ & 0.6 & $\begin{array}{r}58.8 \\
4.2\end{array}$ & $\begin{array}{r}35.3 \\
3.6\end{array}$ & $\begin{array}{r}113.1 \\
11.4\end{array}$ & $\begin{array}{r}46.1 \\
4.7\end{array}$ & 700.0 \\
\hline $48 \mathrm{RJ}$ & $\begin{array}{l}\mathrm{E}_{260} \\
\mu \mathrm{mol}\end{array}$ & 20.2 & 24.1 & $\begin{array}{r}339.6 \\
24.1\end{array}$ & $\begin{array}{l}5.1 \\
0.3\end{array}$ & $\begin{array}{r}45.1 \\
3.4\end{array}$ & 3.1 & $\begin{array}{r}47.4 \\
4.8\end{array}$ & 1.2 & $\begin{array}{r}55.5 \\
3.9\end{array}$ & $\begin{array}{r}25.7 \\
2.6\end{array}$ & $\begin{array}{r}122.5 \\
12.4\end{array}$ & $\begin{array}{r}59.7 \\
6.1\end{array}$ & 749.1 \\
\hline $72 \mathrm{RJ}$ & $\begin{array}{l}\mathrm{E}_{260} \\
\mu \mathrm{mol}\end{array}$ & 35.5 & 20.7 & $\begin{array}{r}278.9 \\
19.8\end{array}$ & $\begin{array}{l}4.0 \\
0.3\end{array}$ & $\begin{array}{r}44.2 \\
3.3\end{array}$ & 2.7 & $\begin{array}{r}55.0 \\
5.6\end{array}$ & 1.0 & $\begin{array}{r}32.8 \\
2.3\end{array}$ & $\begin{array}{r}20.7 \\
2.1\end{array}$ & $\begin{array}{r}88.9 \\
9.0\end{array}$ & $\begin{array}{r}29.2 \\
2.9\end{array}$ & 613.7 \\
\hline $\begin{array}{l}\text { Commer- } \\
\text { cial RJ }\end{array}$ & $\begin{array}{l}\mathrm{E}_{260} \\
\mu \mathrm{mol}\end{array}$ & 76.6 & 20.4 & $\begin{array}{r}281.2 \\
19.9\end{array}$ & $\begin{array}{r}13.1 \\
0.9\end{array}$ & $\begin{array}{r}32.0 \\
2.4\end{array}$ & 2.0 & $\begin{array}{r}37.1 \\
3.8\end{array}$ & 1.0 & $\begin{array}{r}15.6 \\
1.6\end{array}$ & $\begin{array}{r}24.2 \\
2.4\end{array}$ & $\begin{array}{r}92.6 \\
9.4\end{array}$ & $\begin{array}{r}13.4 \\
1.3\end{array}$ & 609.6 \\
\hline $\begin{array}{l}\text { Worker } \\
\text { Jelly }\end{array}$ & $\begin{array}{l}\mathrm{E}_{260} \\
\mu \mathrm{mol}\end{array}$ & 54.9 & 12.7 & $\begin{array}{r}315.7 \\
22.3\end{array}$ & trace & $\begin{array}{r}42.5 \\
3.2\end{array}$ & 6.3 & $\begin{array}{r}25.1 \\
2.5\end{array}$ & & $\begin{array}{l}7.1 \\
0.5\end{array}$ & $\begin{array}{r}26.8 \\
2.7\end{array}$ & $\begin{array}{r}98.3 \\
9.9\end{array}$ & $\begin{array}{r}22.4 \\
2.3\end{array}$ & 611.9 \\
\hline
\end{tabular}


paper chromatography and electrophoresis, UDP was not found in this fraction after hydrolyzing with $0.01 \mathrm{~N} \mathrm{HCl}$ for $30 \mathrm{~min}$ at $100^{\circ} \mathrm{C}$. Both fractions gave a faint color with ninhydrin on paper and thin-layer chromatograms.

The contents of acid soluble nucleotides in each sample were estimated by measuring the ultraviolet absorbance at $260 \mathrm{~m} \mu\left(\mathrm{E}_{260}\right)$ and shown in Table 1.

\section{DISCUSSION}

In the course of the identification of acid-soluble nucleotides in royal jelly and worker jelly, the differences were not found in quality but in quantity in each sample. The total amount of acid-soluble nucleotides was highest in $48 \mathrm{RJ}\left(\mathrm{E}_{260}=\right.$ $749.1 / \mathrm{g}$ ) and considerably small in $72 \mathrm{RJ}$, commercial RJ and worker jelly. The rates of base composition of total nucleotides were approximately same in each sample, about 50 per cent adenosine, which was dominant, about 30 per cent uridine, 5 to 7 per cent guanosine and small amount of cytidine nucleotides. The amount of $260 \mathrm{~m} \mu$ absorbing substances, which were not absorbed in the column of Dowex-1 (fraction A to B) was higher in commercial RJ and worker jelly $\left(E_{260}\right.$ $=76.6$ and 54.9 respectively) than others. The increase in amount of these substances was probably caused by decomposition of nucleotides. Fraction $\mathrm{C}$ was found in small amount in worker jelly, about half as much as in any other samples. The content of fraction $\mathrm{E}$ was fairly large in commercial RJ while it was little in worker jelly, it's trace was found. Commercial RJ and worker jelly had rather low concentration of UMP than others.

UDP and UDP-sugar type nucleotides (fraction $\mathrm{I}$ to $\mathrm{K}$ ) were found in large amount in royal jelly which was taken from early stage of queen cells and had a tendency to decrease in amount as stages of queen larvae advanced and storage period was prolonged. Orotic acid is found in the milk of some domestic animals while it is completely absent in royal jelly and worker jelly.

As mentioned above, the contents of acid-soluble nucleotides are different in each royal jelly sample according to the stage of larvae and storage periods. It is, however, obscure whether these quantitative differences might be of nutritional significance. The relationship of nucleotides to queen differentiation remains to be clarified. This is studied subsequently by rearing test using the honey bee larvae in laboratories.

\section{ACKNOWLEDGEMENTS}

The authors thank Dr. M. Kuwabara, Prof. of Kyushu University, and Dr. S. Ando, Research Laboratories of Chugai Pharmaceutical Co. Ltd., for their valuable suggestions: Dr. T. Yamasaki, Prof. of the University of Tokyo, for his review of this manuscript, and Dr. $T$. Akiba and Dr. H. SANo, Research Laboratories of Chugai Pharmaceutical Co. Ltd.. for permission to publish this work.

\section{REFERENCES}

Allen, R. J. (1940) The estimation of phosphorus. Biochem. J. $34: 858-865$.

Block, J. R., E. L. Durrum and G. Zweig (1958) A Manual of Paper Chromatography and Electrophoresis (2nd Ed.). Academic Press Inc., New York and London, 710 PP. 
Busch, H., R. B. Hurlbert and V. R. Potter (1952) Anion exchange chromatography of acids of the citric acid cycle. J. Biol. Chem. $196: 717-727$.

Chargaff, E. and J. N. Davidson (1955) The Nucleic Acids I, Acadmic Press Inc., New York and London, 692 PP.

Hems, G. (1959) A mildly alkaline ( $\mathrm{pH} \mathrm{8)} \mathrm{solvent} \mathrm{for} \mathrm{the} \mathrm{isolation,} \mathrm{by} \mathrm{paper} \mathrm{chromatography,}$ of purines, pyrimidines, and their nucleosides and nucleotides. Arch. Biochem. Biophys. 82 : 485-487.

Hurlbart, R. B., H. Schmitz, A. F. Brumm and V. R. Potter (1954) Nucleotide metabolism II. Chromatographic separation of acid-soluble nucleotides. J. Biol. Chem. 209 : 23-39.

Jomke, T. (1963) Acid-soluble nucleotides of colostrum, milk, and mammary gland. J. Biochem. $54: 388-397$.

Marko, P. and I. Pechan (1964) Some phosphorus compounds in royal jelly. Nature 189: 188 $-189$.

Mitsui, T., T. Sagawa and H. Sano (1964) Studies on rearing honey bee larvae in the laboratory. I. The effect of royal jelly taken from different ages of queen cells on queen differentiation. J. Econ. Entomol. 57 : 518-521.

Rembold H. (1961) Die Entstehung der Bienenkönigin. Die Zusammensetzung des Weiselzellenfuttersaftes. Umschau $16: 488-491$.

Stahl, E. and U. Kalenbach (1961) Thin-layer chromatography. VI. Trace analysis of sugar mixtures on layers of Kieselguhr G. J. Chromatography 5 : 351-355. 